\title{
Corporate Debt Maturity Choice in Emerging Financial Markets*
}

\author{
May 3, 2010
}

Andreas Stephan
Jönköping International Business School, DIW Berlin, CESIS Stockholm

Oleksandr Talavera

University of East Anglia

Andriy Tsapin

European University Viadrina

\footnotetext{
${ }^{*}$ We thank Oleksandr Antonenko for his excellent research assistance. We are grateful to the editor as well the anonymous referees for their insightful comments and helpful suggestions. We also thank the participants of the 2008 annual conference of the German Economic Association and the participants of the 2008 Spring Meeting of Young Economists. The usual disclaimer applies. Corresponding author: Andriy Tsapin, e-mail: andriy.tsapin@gmail.com.
} 
Corporate Debt Maturity Choice in Emerging Financial Markets

\begin{abstract}
This paper investigates the determinants of liability maturity choice in emerging markets using a unique panel of 4,500 Ukrainian firms during the period 2000-2006. Our estimates confirm the importance of agency costs, liquidity, signaling, and taxes for the liability term structure of firms operating in a transition economy. Companies have a demand for long-term external debt mainly due to the shortage of internal funds. Firm creditworthiness and access to long-term financing at bond markets are the key drivers of corporate debt structure. Overall, this study provides strong evidence that constrained and unconstrained companies react differently on liquidity risk and, hence, pursue different debt maturity strategies. As predicted by the theory, our empirical findings demonstrate an adverse effect of retained earnings on debt maturity but a positive relationship between the tax rate and long-term debt.
\end{abstract}

Keywords: debt maturity, capital structure, transition period, Ukraine.

JEL Classification Numbers: G32, G30, D24. 


\section{Introduction}

The optimal term structure of corporate debt has attracted considerable attention among financiers and economists. Along with leverage, liquidity, and dividend policies, managers also choose the debt maturity structure to maximize the value of their firm. Importantly, sound and developed financial systems substantially facilitate this "tuning" of capital structure, while emerging markets are imputed to have some restrictions that thwart firms to set up the optimal debt maturity. Specifically, due to lower profitability and limited access to markets companies in developing countries use considerably less long-term debt in comparison with their counterparts in developed countries (Caprio and Demirgüc-Kunt, 1998; Schmukler and Vesperoni, 2006). In this article we extend this literature by sheding light onto the key hypotheses of the debt maturity choice in an undeveloped financial environment, a topic thus far neglected in the literature.

Generally, three non-mutually exclusive theories on the choice of liability maturity structure have been developed in financial literature: the contracting-cost hypothesis, the asymmetric information hypothesis, and tax hypothesis (Barclay and Smith, 1995). ${ }^{1}$

The contracting-cost hypothesis argues that agency costs lead to an under-investment problem, if projects with positive net present value are not undertaken. As a partial solution of the conflict between equityholders and bondholders, companies decrease the maturity of their debt liabilities (Myers, 1977). Considering investment as real options, the firms employ shorter-maturity debt to have more growth options in their investment opportunities. Debt that matures before execution of investment options cannot lead to suboptimal investment decisions.

The asymmetric information setup leads to the signalling and liquidity hypotheses. The signalling explanation states that issuance of short-term debt is a positive signal of the firm's low credit risk (Kale and Noe, 1990). Flannery (1986) argues that undervalued companies prefer high priority claims (e.g. secured short-term debt) to indicate their

\footnotetext{
${ }^{1}$ Some authors (e.g. Guedes and Opler, 1996) distinguish the asymmetric information hypothesis with respect to the liquidity-screening hypothesis and asymmetric information hypothesis. However, both are based on asymmetric information framework and we consider these two arguments together.
} 
creditworthiness, while their low-quality counterparts favor long-term debt because they cannot afford to roll over short-term debt in case of positive transaction costs. As an improved credit rating leads to a lower risk premium, debt maturity is negatively related to firm quality. Supporting the liquidity argument, Diamond (1991b) finds that firms with the highest credit rankings prefer to issue short-term debt because of small refinancing risks. This conjecture again implies a negative relationship as better performing firms are more likely to avoid a "crisis at maturity".

Finally, the tax hypothesis analyzes the tax implications of the debt maturity choice. For example, Brick and Ravid (1985) find that the firms employ more long-term debt when the term structure has a positive slope. Higher-priced long term debt enables the firm to avoid more taxes: an effect that is the more attractive the higher the firm's profitability.

However, a number of the assumptions made in the literature regarding the determinants of debt maturity are not plausible or require modification for firms operating in transition markets (Demirgüc-Kunt and Maksimovic, 1998). For example, in underdeveloped financial markets, companies are forced to use relatively expensive external funds. The volatility of the macroeconomic environment and the absence of a credit history increase the likelihood of both loan denial and default premium. Additionally, a smaller variety of products is available on the market and the borrowers are not able to send proper signals about their qualities. Therefore, the insights from the developed countries have to be revisited and confirmed in an emerging markets framework. ${ }^{2}$

The propositions are tested using a unique panel of 4,500 Ukrainian firms during years 2000-2006. We find that debt maturity choices are significantly affected by firm quality and its access to long-term capital markets. The results of this study provide support for maturity matching, agency cost, liquidity, and signaling as being key to

\footnotetext{
${ }^{2}$ In a previous working paper version of this article (Stephan, Talavera and Tsapin, 2008), we model the behavior of a firm that chooses its optimal structure of liabilities. The theoretical model incorporates the tax, liquidity risk, and maturity matching hypotheses. The setup involves managers who make financial and investment decisions so as to maximize the value of the second period undertaking. In the first period, the company is engaged in designing a process for creating its products. To launch the enterprise, short- and long-term debt are used to finance the fixed and working capital, respectively.
} 
choosing higher debt maturity. However, financial constraints play a role in explanation of debt maturity choice. In particular, higher liquidity ratio makes firms to be very sensitive to ROA and tax charges when choosing optimal liabilities structure.

The rest of the paper is organized as follows. Section 2 provides a review of the relevant literature. The peculiarities of debt maturity choice during the transition period in Ukraine are described in Section 3. Section 4 presents the data, while empirical results are discussed in section 5. Section 6 concludes.

\section{Literature Review and Hypotheses}

Researchers have expended considerable effort in trying to understand the optimal capital structure. ${ }^{3}$ Notably, they advance beyond traditional debt-equity trade-off by investigating the liabilities structure itself. ${ }^{4}$ Considering the fact that debt maturity is one of the key characteristics of the right side of the balance sheet, it is only natural to do So.

The financial literature suggests three main explanations for using short- and/or longterm debt (Barclay and Smith, 1995; Emery, 2001). One group of underlaying theories is based on agency (contracting) costs. Early theoretical papers (Jensen, 1986; Bolton and Scharfstein, 1990) emphasize the role of debt in reducing agency costs between shareholders and managers. In a seminal paper, Myers (1977) investigates possible debt externalities of firms' optimal investment policy. Importantly, he finds that short-term debt alleviates the "under-investment" problem when firms are reluctant to pursue relatively riskier projects because creditors get more benefits from these investments. ${ }^{5}$ The under-investment problem is argued to be more severe if a firm has more growth opportunities. Moreover, firms that grow very quickly may be severely constrained because their financing needs exceed their internal resources (Demirgüc-Kunt and Maksimovic, 1998).

\footnotetext{
${ }^{3}$ See Harris and Raviv (1991) for a comprehensive literature review on determinants of capital structure.

${ }^{4}$ Throughout the paper, we use terms liabilities and debt interchangeably.

${ }^{5}$ Myers (1977) suggests three ways to cope with under-investment problem: decrease debt in a capital structure, include restrictive covenants in an agreement, or shorten the effective mature of debt.
} 
Binks and Ennew (1996) point out that the faster the company's growth, the more restricted is their access to credit owing to the considerable gap between the collateral valuation of newly acquired assets and their costs. Additionally, firms have an incentive to switch low-risk to high-risk assets if they employ risky debt that is known as asset substitution issue.

Short-term debt is less sensitive to shifts in the risk and decreases the agency costs by imposing more frequent monitoring by investors. In line with these results, Barnea, Haugen and Senbet (1980) argue that shortening the maturity structure of liabilities to match the structure of assets (maturity matching) can help to reduce the agency costs of under-investment and risk-shifting. This theoretical analysis has resulted in a number of empirical investigations. The majority of studies are consistent with the contracting costs explanation of liabilities maturity (Guedes and Opler, 1996; Heyman, Deloof and Ooghe, 2008; Ortiz-Molina and Penas, 2008). Demirgüc-Kunt and Maksimovic (1999), for instance, show that firms employ short-term funds to finance current assets, which vary with sales.

Higher agency-related costs also are ascribed to smaller companies because their managers on average own a larger proportion of the equity. This aligns the interests of the managers with those of the shareholders but makes these managers to be less risk averse. An additional reason to reenforce agency conflicts is that the investment opportunity of small firms usually are large relative to collaterizable assets (Whited, 1992). In contrast, large companies are more transparent and thus creditors can obtain more accurate information on them at relatively low cost. Moreover, larger firms are considered to have a lower risk of bankruptcy and, thus, they face fewer constraints on obtaining external financing (Chittenden, Hall and Hutchison, 1996). Large firms take advantage of scale economies and tend to employ more long-term debt because of lower fixed (and overall) costs and easier access, while their smaller counterparts are prone to rely on shorter maturity financing with lower transaction costs (Titman and Wessels, 1988). Our hypotheses regarding agency costs and our operationalization in the empirical analyses are displayed in Table 1. As short-term debt is suggested to reduce 
agency costs, we expect that firm size and asset maturity positively affect debt maturity, while higher growth opportunities are associated with lower debt maturity that allows mitigating the agency conflicts.

Another group of explanations is related to asymmetric information about quality of borrowers. Under this condition firms attempt to reveal their qualities by signaling. For examples, these signals could take form of dividends (Bhattacharya, 1979; Miller and Rock, 1985), leverage (Ross, 1977; Poitevin, 1989), or short term debt (Flannery, 1986; Diamond, 1991a). However, the interpretation regarding debt maturity signals is quite controversial. For example, Flannery (1986) derives a separating equilibrium with positive transaction costs in which riskier borrowers are not able to cover costs of rolling short-term debt and prefer long-term debt, while low-risk borrowers stick to short-term debt. Kale and Noe (1990) suggest that similar separating equilibrium is possible even in framework without transaction costs. The latter theoretical issue also is supported empirically by Stohs and Mauer (1996) who find that maturity structure is inversely related to earning surprises (a proxy used for firm quality). Thus, firms with high creditworthiness prefer short-term debt (see Table 1).

Unlike their peers, high-ranked firms are characterized by relatively low exposure to credit risks that makes it possible to issue short-term debt. Budina, Garresten and de Jorg (2000) point out that liquidity risk and liquidity constraints matter more for firms with comparatively large stock of debt. That is why Stohs and Mauer (1996) recommend to control for leverage when testing the effect of liquidity risk on debt maturity because the effectivity of monitoring depends on the borrower's rating. Stohs and Mauer (1996) note that there is no reason for firms with low level of leverage to avoid short-term debt because they have low liquidity risk, while their counterparts are more prone to prolong their liabilities to minimize the risk of refinancing. According to the mentioned above arguments we predict that liquidity risk (inverse measure to Current ratio) has a negative impact on debt maturity in combination with high leverage (see Table 1). Importantly, the access to external funds relaxes existing liquidity constraints, while financial frictions and the induced high price for obtaining accurate information increase the price of 
long-term debt shortening debt maturity (Love, 2003; Jaramillo and Schintarelli, 2002; Schmukler and Vesperoni, 2006). Therefore, the access to capital markets is an essential determinant that influences positively the corporate debt structure (cf. to Table 1).

Finally, tax reasonings constitute the final group of explanations. A number of studies (Brick and Ravid, 1985; Kane, Marcus and McDonald, 1985) highlight the tax advantages of long-term debt. If the yield curve slopes upward, the savings from tax shield value of long-term debt are accelerated by increasing the proportion of debt payments. However, when leverage and debt maturity are chosen simultaneously, taxation might not have any effect on the optimal effect on optimal debt maturity structure (Lewis, 1990). Supporting the latter argument, Ozkan (2002) finds no evidence between debt maturity and total tax charged divided by total taxable income. Similar outcomes are observed in Smith and Stulz (1985) who include a stand-alone yield curve variable into their econometric specification and receive either insignificant or wrongly signed coefficients. For the empirical analysis we can therefore conclude, that the benefits of the tax shield depend on the term structure of interest rates. A positive association between debt maturity and the tax rate is in accordance with the idea that a firm raises its value by issuing long-term debt that guarantees that the tax shield will be in place for a longer duration (Newberry and Novack, 1999). Alternatively, Kane et al. (1985) predict a negative relation between debt maturity and the tax rate because companies compare the remaining tax advantage of debt and amortized flotation costs. Thus, we do not have any ex-ante expectation regarding the impact of taxes on debt maturity choice in our empirical analysis (Table 1).

There are a number of other important factors which affect on leverage and debt maturity. The impact of product market consideration on capital structure is discussed in Titman and Wessels (1988) who find that firms with unique specialized products have lower leverage ratios. Employing US newspaper industry data, Schargrodsky (2002) suggests that oligopolies have higher debt ratios than monopolies. Showalter (1999) investigates how cost and demand uncertainties affect capital structure. Interestingly, he finds that demand uncertainty has stimulating effects on leverage, while cost uncertainty 
decreases borrowing. Sarkar (1999) finds an inverse relationship between the optimal debt maturity and earnings volatility. Finally, Emery (2001) develops a model in which short-term debt has a positive effect on amplitudes of production and investment cycles.

The majority of capital structure-related papers employ data from financially developed countries; research on developing or emerging market countries is still scarce and based mostly on multi-country studies. Booth, Aivazian, Demirgüc-Kunt and Maksimovic (2001) explore capital structure in 10 developing countries. Their estimates are consistent with Pecking-Order hypothesis as one of the main finding is negative link between debt ratio and profitability. Delcoure (2007) investigates determinants of leverage in Czech Republic, Poland, Russia and Slovakia and finds evidence of "modified pecking order": retained earnings, equity, bank and market debt. Nivorozhkin (2004) examines determinants of financial leverage and the speed of adjustment in Czech Republic and Bulgaria. He finds some similarities for target debt ratios in two countries, while speed of adjustment is faster for Bulgarian companies because of differences in financial institutions policies. Demirgüc-Kunt and Maksimovic (1999), analyzing the choice of debt maturity structure in 30 countries, show many similarities in the determinants of debt maturity choice across developed and developing markets. Schmukler and Vesperoni (2006) find that financial liberalization has a negative affect on the maturity structure of firms, operating in emerging countries. While providing important comparative insights these multi-country studies also have a number of hidden pitfalls. The issues are related with heterogeneous accounting standards and each country's sample representativeness. Finally, there are also few single-country studies investigating debt maturity and leverage problems in developing countries. Employing a sample of top 50 Indian business groups, Bandyopadhyay and Kumar Das (2005) find a positive relationship between issuance of short-term securities and product market sales. Chen (2004) suggests that capital structure policies of Chinese listed companies follow "modified pecking order" theory. The findings of Erol (2004) suggest that Turkish firms' debt maturity decision are affected by temporary and stationary shocks to costs and demands.

Although the studies summarized above have examined various aspects of the debt 
maturity in developing countries, we contribute utilizing comparatively rich and large firm-level panel data which enable us considering many hypotheses of previous studies in a single framework. We also advance beyond previous research by creating sub-samples of firms according to different degrees of financial constraints. Utilizing this approach, financial and liquidity constraints can affect firms maturity structure decisions through their impact on other variables which are important for explaining firms' debt maturity choice. Finally, the applied econometric methodology of our study differs from previous empirical studies and has specific advantages as discussed in subsection 5.1 below.

In the next section, we describe the environment in which the companies contained in our sample operate.

\section{Emerging Financial Markets and Corporate Finance in Ukraine}

After the collapse of Soviet Union, Ukrainian firms faced numerous market imperfections that hampered access to information and adequate external financing. The problem was partly caused by lack of an appropriate legislative basis for the financial system, legislation that finally began to be enacted in 1995, but not completed until $2000 .{ }^{6}$ In 1998, a sudden crisis revealed the fragility of the Ukrainian financial market. Subsequent financial defaults created numerous distortions in the financial system. Although the National Bank of Ukraine (NBU) was eventually successful in overcoming this problem and revitalized the financial and credit markets, leading to stabilization, economic agents reacted very slowly to these positive developments. Ukrainian firms faced constant difficulty in obtaining sufficient financing, since a high level of system uncertainty and insufficient financial intermediation triggered high prices for financial resources. ${ }^{7}$ In this environment, enterprises looked for cheaper finance alternatives, including, for example,

\footnotetext{
${ }^{6}$ Principles and pathways for capital market development were fixed in several Laws of Ukraine, including "On State Regulation of Securities Market in Ukraine" (1996), "On the National Bank of Ukraine" (1999), and "On Banks and Banking" (2000).

${ }^{7}$ The main reasons for the shortage of long-term finance were a high inflation rate and unstable macroeconomic policy.
} 
barter, trade credits, and postponed tax liabilities. ${ }^{8}$

The economy's negative tendency (e.g. real GDP growth) persisted until 19992000. And even then, despite some progress, many issues remained unsolved. A prolonged recession, coupled with postponed restructuring, aggravated the financial crisis of Ukrainian companies. It appeared that the companies' growing financial needs could not be met solely with internal funds. Firms' demand for external financing increased, even in the face of very high costs of same. Specifically, the observed convergence of interest rates is considered by experts to be attributed to the development of financial markets. However, market imperfections led to there being very few alternatives to bank loans as a method of financing. Only 18 percent of companies considered stock issue as the most important way to finance (SCSSM, 2004). The State Commission on Securities and Stock Market reported that more than half of the joint stock companies (59 percent) intended to apply for a bank loan in 2004.

The development of a financial sector simplified access to bank financing. The marked increase in bank lending (from 61 percent to about 93 percent of broad money during the period of investigation) led to a growing role for long-term liabilities. While the banks' share of long-term assets was only 18 percent in 2000, it reached 55 percent in 2006 . In 2005 Ukrainian banks started to grant credits in foreign currency that encouraged economic agents to apply for long-term financing more intensively due to the lower interest rate as a result of the lower volatility of the alternative currency. ${ }^{9}$

Notably that the relatively low nominal interest rates do not coincide with effective interest rates. For example, since Ukrainian banks find it difficult to make an accurate assessment of a borrower's credit rating, they tend to increase the price of lending, which comprises both default and liquidity components. As there is a great deal of uncertainty as to the default risk, the debt payments incorporate not only transaction costs but also other commission charges in case of long-term debt, e.g., commission for

\footnotetext{
${ }^{8}$ For instance, in 1999, the barter share was 24 percent of all payments (World Business Environment Survey, World Bank-EBRD, 1999).

${ }^{9}$ However, this type of loans appeared to be the most exposed during the following financial crisis in 2008 and caused numerous bankruptcies after the fall in exchange.
} 
early repayment. ${ }^{10}$ Duenwald, Gueorguiev and Schaechter (2005) point out that the absence of alternative sources of corporate financing in transition financial markets has induced banks to compete with each other over credit terms (e.g., the range and fees for services), rather than on the basis of interest rates.

In addition, bank preferences might distort corporate debt maturity choices as Ukrainian banks avoid lending money to newer and riskier firms and industries (Dewatripont and Maskin, 1995). At the same time, nonbank intermediaries, which are more willing to finance risky projects, are underdeveloped in Ukraine. ${ }^{11}$ Thus, banks might discriminate against clients with respect to loan covenants and debt maturity in particular.

In short, Ukrainian firms faced many obstacles to implementing a reasonable debt policy and the country thus provides an interesting illustration of the motivations behind debt maturity choice in a transition period.

\section{Data}

\subsection{Sample overview}

We use a panel of open joint stock companies during the period 2000-2006 that was collected by SMIDA (The State Commission on Securities and Stock Market). The dataset includes detailed information on balance sheet and income of Ukrainian companies. To discard outliers, firm-level variables are truncated at the most extreme (top and bottom) one percent level of the distribution on an annual basis. To reduce data errors, we keep only those firms that report positive sales. After these screening procedures, our data contains about 4,500 firms and 17,500 firm-year observations in total.

Table 2 contains descriptive statistics for the variables used in the regression analysis (LTD/TD, Leverage, ROA, Volatility, Size, Turnover, Current Ratio, Tax, Growth, Asset Maturity, and Access). LTD/TD is defined as the ratio of long-term debt

\footnotetext{
${ }^{10}$ Budina et al. (2000) argue that a firm-specific premium is required by banks because of inability to monitor all aspects of investment projects.

${ }^{11}$ For example, Tadesse (2002) finds that bank-based systems better promote economic growth in case of underdeveloped financial sectors.
} 
to total debt. Overall, we find a low level of average long-term debt. However, the large variation in long-term debt (0.178) relative to the mean (0.087) understates the level of long-term debt because many Ukrainian firms (about 57 percent) have no longterm debt at all. Firms that have no long-term liabilities are on average smaller, more profitable, have lower leverage ratio, and have notably larger turnover (1.00 vs 0.85 for their counterparts). Apparently, companies without long-term debt face less severe cash constraints and prefer financing by internal funds. Actually, a higher level of debt maturity is intrinsic to less constrained firms.

The firms in our sample also demonstrate a lack of internal financial resources on average (Table 2), as the mean of retained earnings to total assets ratio $(R O A)$ is about -1.4 percent, and there is a considerable heterogeneity in corporate profitability too. Limited access to external funds is a main problem of transition financial markets. Specifically, our proxy for the access to capital markets (Access) indicates that only about 8.1 percent of firms have issued bonds during the observation period.

Additionally, the average annual growth rate of 130 percent is very high and Ukrainian corporations have on average improved their quality proxied by the turnover to asset ratio. However, the mean of Asset Maturity (1.11) is rather attributed to obsolete assets firms dispose than to a high replacement rate. This possibly affects the non-debt-related corporate tax shield, while the low mean of tax rate (13.4 percent) is due to the fact that only a part of the firms have chargeable earnings. ${ }^{12}$

The governmental sector holds substantial shares in about 16 percent of firms in our sample. It can be noted that state-controlled firms on average have a lower share of long-term debt in their corporate liabilities (7.4 percent against 8.4 percent for their peers). ${ }^{13}$

\footnotetext{
${ }^{12}$ It is also noteworthy that most correlations between the variables are in accordance with the expectations from our hypotheses. The matrix of correlation coefficients is available from the authors upon request.

${ }^{13} \mathrm{~A}$ Wilcoxon rank-sum test on the difference in debt maturity between state-controlled and privatecontrolled firms, however, is not significant at the $10 \%$ level.
} 


\subsection{Financially constrained companies}

According to our theory, financial frictions make the price of long-term debt exorbitantly high hindering the access to external funds. To examine this argument we need to distinguish between financially constrained and unconstrained companies. In the relevant literature there are many reasonable approaches to separate firms depending on the financial frictions they face. In this study we use three alternative but complementary schemes to split our sample into subsamples.

First, to explore the impact of financial constraints on debt maturity issue we cleave our sample into two groups that will be referred to as financially constrained and financially unconstrained basing on their size in terms of total assets $(T A)$. This division is based on the presumption that smaller firms face more difficulties in accessing external finance because they are subject to greater asymmetric information and endure more severe agency problems. Moreover, creditors are more willing to finance larger borrowers because the larger amount of total assets creates a guarantee effect (Holmstrom and Tirole, 1997). Therefore, we rank companies based on their size and assign to the financially constrained (unconstrained) category those firms whose size is below (above) the median size value in our sample.

Table 3 documents the key descriptive statistics for small and large firms. The significance of the difference in means between the two groups of firms is determined using the non-parametric Wilcoxon rank-sum test which is robust even when the distribution of a variable is skewed. Most of the variables except Growth are notably different across different sub-samples (Table 3). These differences are significant at the one percent level. Overall, the results indicate that large companies have, on average, higher longterm leverage (i.e., lower short-term leverage) and their overall leverage ratios are quite different from those for small firms. Additionally, large companies have better financial key characteristics which stipulate the availability of credits. Specifically, higher ROA and Asset Maturity as well as lower Volatility indicate better creditworthiness of these firms in comparison to their peers.

Second, we also consider the two subsamples of firms divided on the basis of their 
liquidity constraints to get insight into the relevance of financial constraints. A firm is defined as financially constrained (unconstrained) if the level of their Current Ratio falls below (above) the median value in the sample. Thus, it is presumed that firms face liquidity constraints if they do not have sufficient cash to finance their operating activity. The most intriguing observation in Table 4 is that firms with severe liquidity constraints are able to receive better access to external finance despite of a worse profitability and notably higher volatility of retained earnings. An obvious advantage of constrained companies is their higher ability to pledge because they have the assets of better quality. Apparently, the low indebtedness of unconstrained firms can be explained as these firms have enough internal funds and there is no further need to turn to expensive external financing. In particular, unconstrained firms may share many features like Turnover with their counterparts.

Finally, this study investigates the relevance of our hypotheses for sub-samples of firms which have access or no access to bond markets. We retrieve data on firms' bond issues and mark the companies that report public debt during the period of observation as firms with access to capital markets. The presumption is that firms with access to capital markets are financially less constraint and furthermore firms that have access to bonds get a quality assessment performed by market (Whited, 1992). The results in Table 5 for the difference tests on means show that long-term debt (short-term debt) is significantly higher (lower) for firms with access than for those without. However, in other aspects, these two subsamples are quite similar. In particular, the test statistics do not confirm differences in firm growth opportunities, volatility of retained earnings, and tax charge (Table 5). On the other hand, important variables including Size, Leverage, and Asset Maturity are notably different across the sub-samples, suggesting that the differences in access to capital markets reflects also firm-specific characteristics. Companies with access to financial markets are on average larger (variable Size) and have assets of better quality (variable Asset Maturity). 


\section{Empirical implementation}

\subsection{Econometric Models}

Table 1 summarizes our hypotheses and describes the variables and expected signs. The long-term debt $(L T D)$ is a stock variable that reflects the cumulative result of debt decisions in the past. Note that long-term debt is defined as long-term liabilities having a duration of more than one year. ${ }^{14}$ Even though this definition is different from definitions used in papers investigating debt maturity choice in Western economies, it is appropriate to have a shorter cut for firms operating in underdeveloped financial environment. ${ }^{15}$ Thus, Debt Maturity ${ }_{i t}$ denotes the share of long-term leverage in total debt $(L T D / T D)$ throughout the paper.

To examine the corporate debt maturity choice of Ukrainian joint stock companies, we specify the expression for debt maturity as a linear function of the firm size, return on assets, volatility of retained earnings, tax rate, turnover, current ratio and growth opportunities, access to capital markets, leverage, and asset maturity.

$$
\begin{aligned}
\text { DebtMaturity }_{i t} & =\beta_{0}+\beta_{1}(\text { Size })_{i t-1}+\beta_{2}(\text { ROA })_{i t-1}+\beta_{3}(\text { Turnover })_{i t-1} \\
& +\beta_{4}(\text { CurrentRatio } \times \text { Leverage })_{i t-1}+\beta_{5}(\text { AssetMaturity })_{i t-1} \\
& +\beta_{6}(\text { Growth })_{i t-1}+\beta_{7}(\text { Volatility })_{i t-1}+\beta_{8}(\text { Tax })_{i t-1} \\
& +\beta_{9}(\text { Access })_{i t}+\mu_{i}+\tau_{t}+\epsilon_{i t}
\end{aligned}
$$

where the subscript $i$ refers to firms and the subscript $t$ to periods, $\mu_{i}$ and $\tau_{t}$ are firm and time effects, respectively. Finally, $\epsilon_{i t}$ denotes the error term. To reduce the problem of possible endogeneity, the right-hand side of this equation comprises lagged

\footnotetext{
${ }^{14}$ According to "Standards of Accounting in Ukraine", long-term liabilities are defined as those not included in current liabilities. Long-term debt comprises bank loans, prolonged liabilities, other financial long-term liabilities, and other long-term liabilities with a duration of more than one year.

${ }^{15}$ Ozkan (2002), in his analysis of U.K. companies, distinguishes between three types of debt: (i) current (borrowing repayable in one year), (ii) short term (loans due within five years), and (iii) longterm loans (loans for more than five years). Guedes and Opler (1996) consider long-term debt of U.S. corporations to be that with a term that exceeds 30 years.
} 
values of the explanatory variables instead of current ones. Furthermore, time dummies (not reported) are included in all regressions to account for macroeconomic disturbances.

We perform censored regressions because the dependent variable is the share of longterm debt in total debt and therefore is restricted to the range from zero to one. In addition, a large number of firms do not have any long-term liabilities. As firm heterogeneity is likely to be important for debt maturiy choice, we specifiy Tobit models with random (RE) and fixed (FE) effects in the estimations. Note that if firm-specific effects and the explanatory variables are correlated, then the fixed-effects Tobit model is expected to give more reliable estimates. ${ }^{16}$

The Tobit model with fixed effects can be written as follows:

$$
\begin{gathered}
y_{i t}^{*}=\alpha_{i}+x_{i t} \beta+\varepsilon_{i t}, \\
y_{i t}=\max \left(0, Y_{i t}^{*}\right) ; \quad \varepsilon_{i t} \sim N\left[0, \sigma_{\varepsilon}^{2}\right],
\end{gathered}
$$

where $y_{i t}^{*}$ is latent variables which are unobserved if $y_{i t}^{*}<0 . x_{i t}$ denotes the vector of observable explanatory variables for the $i$ th firm at the time $t$ and $\beta$ is the vector of parameters. The term $\alpha_{i}$ represents an unobservable individual firm specific effect and $\varepsilon_{i t}$ denotes a random disturbance. ${ }^{17}$

In this model, the explanatory variables influence the conditional mean of debt maturity in the positive part of the distribution. At the same time, regressors affect the probability that the observation will be in this part of the distribution. The marginal effects are evaluated at the sample means of the observations.

A combination of firm size and growth opportunities are generally suggested to be crucial to determine the degree of informational asymmetry and agency costs. Thus, Size and Growth are control variables used to examine the hypothesis about conflicts

\footnotetext{
${ }^{16}$ It should be noted that the Tobit model with fixed effects produces biased estimates due to the incidental parameter problem, however, the bias is neglible small (Greene, 2004).

${ }^{17}$ The econometric software LIMDEP 9.0 provides a procedure to obtain estimates of the Tobit model with fixed effects.
} 
between shareholders, managers, and creditors. The former is measured as the natural logarithm of total assets, while the latter is defined as the sales growth to total assets growth ratio.

Companies need to choose an optimal debt structure in order to weaken their dependence on the refinancing decisions of creditors who require a confirmation of creditworthiness. There are several ways a firm can prove it capacity to repay debt: high credit rating, high turnover, and growth opportunities. Obviously, a good credit rating and reputation enhance the probability of obtaining credit. Unfortunately, firm age, which is often used as a proxy for credit rating and reputation, cannot be used as such here because the recent procedure for firm registration in Ukraine causes a bias in relevant data. ${ }^{18}$ The most convenient way to confirm credit quality in an environment of underdeveloped capital markets monopolistic banks is to use collateral. ${ }^{19}$ However, to signal their creditworthiness, Ukrainian firms most likely demonstrate stable turnover or point out their potential, instead of bringing up the issue of collateral, because in many cases the assets that could be considered collateral are hopelessly obsolete and of little value on a competitive market.

Previous studies have used abnormal profit as a proxy for credit quality (Ozkan, 2002). However, many Ukrainian firms conceal their real profit by adjusting their costs to their turnover to avoid excessive scrutiny by taxing authorities. Therefore, we utilize the ratio of sales to total assets, Turnover, as an alternative proxy for abnormal profit. Additionally, our choice of the measure for firm creditworthiness can be explained by the fact that the turnover is recommended by the National bank of Ukraine to be used as a key indicator assessing quality of borrowers. ${ }^{20}$

The volatility of retained earnings as well as the ratio of the firm's current assets to current liabilities (Current Ratio) characterize firm riskiness. Moreover, Current Ratio usually is treated as an indicator of liquidity constraints and/or an adverse measure to

\footnotetext{
${ }^{18}$ Some firms have been operating for a long time but are reregistered as new ones.

${ }^{19}$ Boot and Thakor (1994) argue that collateral is efficient in early stages of a banking relationship to solve moral hazard problems of investment.

${ }^{20}$ See "Provision on proceeding order of formation reserve for coverage possible looses in credit transactions of the banks", approved by Decree of the NBU board as of June 6, $2000 N 279$.
} 
liquidity risk, which is interacted with the firm's debt to total assets ratio, Leverage. Moreover, Access is dummy variable which takes value of one if the firm has access to the bond market, zero otherwise. Besides being an inverse indicator of financial constraints, Access is also related to firm quality evaluated by markets.

We also include Asset Maturity into our econometric specification to examine the maturity matching hypothesis. This variable is constructed as the ratio of net property, plant, and equipment to depreciation expense, allows testing the maturity matching hypothesis. The tax hypothesis might be confirmed by significance of the tax shield variable, Tax, measured as the total tax charged normalized by taxable income.

\subsection{Estimation of the models and discussion of the results}

\subsubsection{Results for All Firms}

We run several sets of regressions and compare the results with respect to different subsamples. The coefficients and marginal effects for the expected value of Debt Maturity ( $L T D / T D)$ conditional on being uncensored are reported in Table 6 . The results of our estimations demonstrate that some variables including Size, Turnover, Asset Maturity, our proxy for Liquidity Risk (Current Ratio*Leverage) and Access appear to be decisive for debt maturity choice. These empirical findings confirm the relevance of agency costs and signaling theories. All these coefficients have the predicted signs and most of them are significant at the one percent level.

The disciplining function of debt maturity receives strong support in this study as the structure of corporate liabilities is used by firms to settle up agency conflicts. In line with Heyman et al. (2008) and Ortiz-Molina and Penas (2008), small firms mainly obtain only short-term credits because of their opaqueness, while firms with high growth opportunities are compelled to lower their debt maturity to reduce agency costs. Additionally, companies adjust cash flows because maturity matching allows them to control the agency conflicts, a conclusion that is in agreement with Morris (1976). At the same time, there is no evidence that agency costs of debt related to the underinvestment problem are lowered by higher earnings volatility. Another equally important 
issue is that the signaling properties of the volatility also are not evident.

However, the results obtained from the estimation of our baseline regression model (1) provide robust evidence to corroborate the signaling and liquidity risk hypotheses (Table $6)$. As expected, there is a negative association between debt maturity and firm credit quality measured by Turnover. This result supports the findings of Flannery (1986) and Harris and Raviv (1991), who suggest that riskier firms with lower creditworthiness try to prolong the maturity of their liabilities as they are crucially dependent on refinancing. This type of behavior appears to be appropriate for firms that are forced to enhance the productivity of their assets; it can be explained as an attempt to avoid an additional burden of long-term interest payments.

The positive coefficient on our proxy for liquidity risk is consistent with arguments that long maturity of debt leads to attenuating this risk, which can be equivalent to reducing expected bankruptcy costs (Johnson, 2003). One result of great importance is that firm creditworthiness and access to long-term financing influence considerably corporate debt maturity choice. The access to capital markets is argued to be a key factor for firms to choose optimal structure of corporate debt. ${ }^{21}$ The access to bond market enables firms to finance about 14.7 percent of their total debt. This result is compatible with the empirical findings realized by Jaramillo and Schintarelli (2002) and Schmukler and Vesperoni (2006).

The influence of taxes on debt maturity is a worthy topic on its own as previous empirical studies have reported quite controversial findings described above. However, the results of our estimations corroborate the idea of (Newberry and Novack, 1999) who assert a positive impact of the tax rate on debt maturity due to higher tax shield for long-term liabilities. This effect can be attained because of upward yield curve or/and the intrinsic structure of corporate debt. Barclay and Smith (1995) argue that the tax-rate coefficient should be positive for the secured debt regression. The latter statement is of particular importance taking into account the nature of debt prevalent

\footnotetext{
${ }^{21}$ We have also checked specifications where access to capital markets are modelled as endogenous dummy variable using a Heckman type model. However, the results do not indicate major changes so we decided to keep the simpler framework.
} 
in case of emerging markets. Thus, the regression outcomes provide strong support for all hypotheses except the influence of the volatility of firm earnings.

\subsubsection{Results for Sub-samples of Firms}

Having established the determinants of debt maturity for the overall sample, we next discuss the results for the sub-samples analysis to shed some light onto the underlying forces that may induce differences in debt maturity choice between different types of companies. The first question we address is whether different degrees of financial frictions affect the structure of corporate debt.

Table 6 sets out the estimated parameters of determinants of debt ratio and debt maturity for small and large firms that are presumed to represent different degrees of financial constraints. We find that both categories of companies have similar features regarding their debt policy. Determinants such as Size, Turnover, Current Ratio, and Access have significant impact on debt maturity for both groups. Note that small companies are more sensitive to these determinants which might restrict their financial activities. Specifically, the amount of total assets (size) and access to long-term finance are more important for smaller firms regarding their debt maturity choice. Smaller companies also do suffer from higher informational asymmetry and are thereby forced to rely more on internal or equity financing. The latter result exposes a common characteristic of underdeveloped markets and makes a reasonable precondition for corroborating our expectation about the influence of retained earnings. A one percent increase in ROA induces small firms to reduce the share of long-term debt in total debt by 5.9 percent, while for their larger counterparts ROA is not decisive for their capital structure. This evidence is equally supports both the contracting and signaling hypotheses, because profitability is an indicator of firm quality and can as well be treated as a proxy to capture potential agency conflicts. It is also worth noting that despite marked differences between the two groups neither small nor large companies are sensitive to earnings volatility with regard to their debt structure choice which seems to be quite intriguing.

Unlike large companies, their peers do not follow maturity matching principles, al- 
though small firms are more likely to be subject to severe agency conflicts and asymmetric information. Plausibly, such behavior of constrained companies confirm their risky status that is also reflected in their limited access to capital markets. At the same time, smaller (constrained) firms are more prone to use the tax shield when considering the structure of corporate liabilities.

Firms with lower liquidity and, hence, severe cash constraints have considerably higher levels of leverage, but with lower debt maturity (Table 4). Obviously, the shortage of liquidity might be partly induced by higher growth ratio. This, in turn, imposes firms to focus on short-term obligations to alleviate under-investment and asset substitution problems and/or to exhibit high firm quality to their borrowers. These predictions are completely confirmed by our estimates. Constrained firms becomes very sensitive to the liquidity risk and growth opportunities when choosing optimal debt maturity (see Table 4). In case of emerging markets signaling is argued to be especially important for constrained firms as they need to look for niche market credit. ${ }^{22}$ In contrast to constrained firms, their counterparts which are able to generate enough cash choose optimal debt maturity taking into account their tax charges. However, the impact of tax rate is considerably higher for companies without liquidity constraints than those detected for all firms.

Finally, in order to comprehend the role of financial constraints in debt maturity choice we consider more closely those firms that are rated by financial markets (Table 7). Note that the outcomes for the groups with and without access to capital markets are quite similar to the results for small and large firm groups. The variables ROA and tax rate are significant determinants of liabilities structure for constrained companies in both cases (see Tables 6 and 7). This effect remains possibly because both companies are characterized by higher level of liquidity in comparison to their less restricted peers. An intriguing finding is that firms with potentially higher agency costs have higher demand

\footnotetext{
${ }^{22}$ Graham, Lemmon and Schallheim (1998) argue that companies with less liquid balance sheets have a greater possibility of using a mortgage to obtain long-term financing. However, tangible assets in the Ukraine are generally very obsolete (about 55 percent of initial value for our sample) and it is reasonable to conclude that firms have few resources to pledge as collateral.
} 
for long-term debt if these firms have access to financial markets. However, other sorts of agency conflicts like those associated with higher growth opportunities predictably are solved by shortening the duration of liabilities or by maturity matching. Our findings support the maturity matching hypothesis for all firms and across different subsamples, whereas growth opportunities only play a role for the debt maturity choice of financially unconstrained companies.

Generally, we find that more constraint firms are more sensitive to the determinants of debt maturity choice. This finding supports the "modified pecking order" theory in explaining capital structure choice of Ukrainian firms (Delcoure, 2007). Additionally, a shortage of liquidity makes firms less susceptive to tax charges when choosing optimal liability structures.

\section{Conclusions}

This paper investigates the determinants of debt maturity choice in transition markets. By employing a panel dataset of balance sheets and income statements from about 4,500 open joint stock Ukrainian companies over the period 2000-2006 we find sufficient evidence to support our hypotheses relating to the relevance of liquidity, signaling, maturity matching, and agency costs. Several features of corporate finance in emerging markets are worth special note. Our study demonstrates that financial frictions and access to capital markets substantially affect corporate debt maturity choice.

The partition of our sample into categories of financially constrained and unconstrained firms allows us to discern some intrinsic features attributed to emerging markets. Overall, this study provides strong evidence that constrained and unconstrained companies react differently on liquidity risk and, hence, pursue different debt maturity strategies. The impact of determinants of debt maturity becomes stronger for those variables which restrict firms' activity. The higher magnitude of corresponding coefficients implies that more constrained companies are more sensitive to the determinants of debt structure, conclusion that can be considered as a proper feature of emerging markets. For instance, if a firm has higher liquidity, then retained earnings and tax rate 
become significant determinants of liabilities structure. As predicted by the theory, our empirical findings demonstrate an adverse effect of retained earnings on debt maturity but on the other hand a positive relationship between the tax rate and long-term debt.

Although our results are informative, we leave some questions unanswered to advance further research. First, there is no evidence about the impact of earnings volatility on debt maturity choice. This subject seems to be an interesting starting point for future work taking into account higher uncertainty attributed to emerging markets. The second issue we point out is to test the reasons for the negative relationship between debt maturity and firm size for companies with access to capital markets. Specifically, one could study whether this result is related to agency costs or more a consequence of information asymmetry.

From the economic policy perspective, our results indicate that firms' liability structures are strongly affected by specific characteristics of transition financial markets, implying that there is a pressing need to facilitate this phase of financial market development toward more stability. Financial market development would remove restrictions on efficient firm investment by reducing financial constraints (Love, 2003). Moreover, it would be useful to implement a legal requirement concerning the reporting of the effective credit rate to avoid confusing debtors and undervaluing their liquidation rates. Banks in transition financial markets charge additional commissions for long-term loans, thus increasing the cost of long-term financing and potentially distorting firms' financial decisions. Our study underlines that underdeveloped transition financial markets are an impediment to prudent long-term financing of companies. 


\section{References}

Bandyopadhyay, A. and Kumar Das, S. (2005), 'The linkage between the firm's financing decisions and real market performance: A panel study of Indian corporate sector', Journal of Economics and Business 57(4), 288-316.

Barclay, M. J. and Smith, C. W. (1995), 'The maturity structure of corporate debt', Journal of Finance 50(2), 609-632.

Barnea, A., Haugen, R. A. and Senbet, L. W. (1980), 'A rationale for debt maturity structure and call provisions in the agency theoretic framework', Journal of Finance 35(5), 1223-1234.

Bhattacharya, S. (1979), 'Imperfect information, dividend policy, and "the bird in the hand" fallacy', Bell Journal of Economics 10(1), 259-270.

Binks, M. R. and Ennew, C. T. (1996), 'Growing firms and the credit constraint', Small Business Economics 8, 17-25.

Bolton, P. and Scharfstein, D. S. (1990), 'A theory of predation based on agency problems in financial contracting', American Economic Review 80(1), 93-106.

Boot, A. and Thakor, A. (1994), 'Moral hazard and secured lending in an infinitely repeated credit market game', International Economic Review (35), 899-920.

Booth, L., Aivazian, V., Demirgüc-Kunt, A. and Maksimovic, V. (2001), 'Capital structures in developing countries', Journal of Finance 56(1), 87-130.

Brick, I. E. and Ravid, A. S. (1985), 'On the relevance of debt maturity structure', Journal of Finance 40(5), 1423-1437.

Budina, N., Garresten, H. and de Jorg, E. (2000), 'Liquidity constraints and investment in transition economies', Economics of Transition 8(2), 453-475.

Caprio, Gerard, J. and Demirgüc-Kunt, A. (1998), 'The role of long-term finance: Theory and evidence', World Bank Research Observer 13(2), 171-189.

Chen, J. J. (2004), 'Determinants of capital structure of chinese-listed companies', Journal of Business Research 57(12), 1341-1351. 
Chittenden, F., Hall, G. and Hutchison, P. (1996), 'Small firm growth, access to capital markets and financial structure: Review of issues and an empirical investigation', Small Business Economics (8), 59-67.

Delcoure, N. (2007), 'The determinants of capital structure in transitional economies', International Review of Economics \& Finance 16(3), 400-415.

Demirgüc-Kunt, A. and Maksimovic, V. (1998), 'Law, finance, and firm growth', Journal of Finance 53(6), 2107-2137.

Demirgüc-Kunt, A. and Maksimovic, V. (1999), 'Institutions, financial markets, and firm debt maturity', Journal of Financial Economics 54, 295-336.

Dewatripont, M. and Maskin, E. (1995), 'Credit efficiency in centralized and decentralized economies', Review of Economic Studies 62, 541-555.

Diamond, D. W. (1991a), 'Debt maturity structure and liquidity risk', Quarterly Journal of Economics 106, 709-737.

Diamond, D. W. (1991b), 'Monitoring and reputation: The choice between bank loans and directly placed debt', Journal of Political Economy 99(4), 689-721.

Duenwald, C., Gueorguiev, N. and Schaechter, A. (2005), Too much of a good thing? Credit booms in transition economies: The cases of Bulgaria, Romania, and Ukraine, Working Paper 128, International Monetary Fund.

Emery, G. W. (2001), 'Cyclical demand and the choice of debt maturity', Journal of Business 74(4), 557-90.

Erol, T. (2004), 'Strategic debt with diverse maturity in developing countries: Industrylevel evidence from Turkey', Emerging Markets Finance and Trade 40(5), 5-24.

Flannery, M. J. (1986), 'Asymmetric information and risky debt maturity choice', Journal of Finance 41(1), 19-37.

Graham, J. R., Lemmon, M. L. and Schallheim, J. S. (1998), 'Debt, leases, taxes, and the endogeneity of corporate tax status', Journal of Finance 53(1), 131-162.

Greene, W. (2004), 'Fixed effects and the incidential parameters problem in the tobit model', Econometric Reviews 23(2), 125-148. 
Guedes, J. and Opler, T. (1996), 'The determinants of the maturity of corporate debt issues', Journal of Finance 51(5), 1809-1833.

Harris, M. and Raviv, A. (1991), 'The theory of capital structure', Journal of Finance 46(1), 297-355.

Heyman, D., Deloof, M. and Ooghe, H. (2008), 'The financial structure of private held Belgian firms', Small Business Economics 30(3), 301-313.

Holmstrom, B. and Tirole, J. (1997), 'Financial intermediation, loanable funds, and the real sector', Quarterly Journal of Economics 112(3), 663-691.

Jaramillo, F. and Schintarelli, F. (2002), Access to long-term debt and effect of firm performance; lessons from Ecuador, Technical report, Inter-American Development Bank.

Jensen, M. C. (1986), 'Agency costs of free cash flow, corporate finance, and takeovers', American Economic Review 76(2), 323-29.

Johnson, S. A. (2003), 'Debt maturity and the effect of growth opportunities and liquidity risk on leverage', Review of Financial Studies 16(1), 209-236.

Kale, J. and Noe, T. (1990), 'Risky debt maturity choice in a sequential game equilibrium', Journal of Financial Research 13, 155-165.

Kane, A., Marcus, A. J. and McDonald, R. L. (1985), 'Debt policy and the rate of return premium to leverage', Journal of Financial and Quantitative Analysis 20(4), 479499.

Lewis, C. M. (1990), 'A multiperiod theory of corporate financial policy under taxation', Journal of Financial and Quantitative Analysis 25(01), 25-43.

Love, I. (2003), 'Financial development and financing constraints: International evidence from the structural investment model', Review of Financial Studies 16(12), 765791.

Miller, M. H. and Rock, K. (1985), 'Dividend policy under asymmetric information', Journal of Finance 40(4), 1031-1051.

Morris, J. R. (1976), 'On corporate debt maturity strategies', Journal of Finance 31(1), 29-37. 
Myers, S. C. (1977), 'Determinants of corporate borrowing', Journal of Financial Economics 5, 147-175.

Newberry, K. J. and Novack, G. F. (1999), 'The effect of taxes on corporate debt maturity decisions: An analysis of public and private bond offerings', Journal of the American Taxation Association 21(2), 1-16.

Nivorozhkin, E. (2004), 'The dynamics of capital structure in transition economies', Economic Change and Restructuring 37(1), 25-45.

Ortiz-Molina, H. and Penas, M. (2008), 'Lending to small businesses: The role of loan maturity in addressing information problems', Small Business Economics $\mathbf{3 0}(4), 361-383$.

Ozkan, A. (2002), 'The determinants of corporate debt maturity: Evidence from UK firms', Applied Financial Economics (12), 19-24.

Poitevin, M. (1989), 'Financial signalling and the "deep-pocket" argument', RAND Journal of Economics 20(1), 26-40.

Ross, S. A. (1977), 'The determination of financial structure: The incentive-signalling approach', Bell Journal of Economics 8(1), 23-40.

Sarkar, S. (1999), 'Illiquidity risk, project characteristics, and the optimal maturity of corporate debt', Journal of Financial Research 22, 353-370.

Schargrodsky, E. (2002), The effect of product market competition on capital structure: Empirical evidence from the newspaper industry, Business School Working Papers, Universidad Torcuato Di Tella.

Schmukler, S. L. and Vesperoni, E. (2006), 'Financial globalization and debt maturity in emerging economies', Journal of Development Economics 79(1), 183-207.

SCSSM (2004), 'Report on the state of corporate management in the joint-stock companies. 2004', Report, State Commission on Securities and Stock Market.

Showalter, D. (1999), 'Strategic debt: Evidence in manufacturing', International Journal of Industrial Organization 17(3), 319-333.

Smith, C. W. and Stulz, R. M. (1985), 'The determinants of firms' hedging policies', Journal of Financial and Quantitative Analysis 20(04), 391-405. 
Stephan, A., Talavera, O. and Tsapin, A. (2008), Corporate debt maturity choice in transition financial markets, Discussion paper 784, DIW Berlin.

Stohs, M. H. and Mauer, D. C. (1996), 'The determinants of corporate debt maturity structure', Journal of Business 69(3), 279-312.

Tadesse, S. (2002), 'Financial architecture and economic performance: International evidence', Journal of Financial Intermediation 11, 429-454.

Titman, S. and Wessels, R. (1988), 'The determinants of capital structure choice', Journal of Finance $\mathbf{4 3}(1), 1-19$.

Whited, T. M. (1992), 'Debt, liquidity constrains, and corporate investment: Evidence from panel data', Journal of Finance 47(4), 1425-1460. 


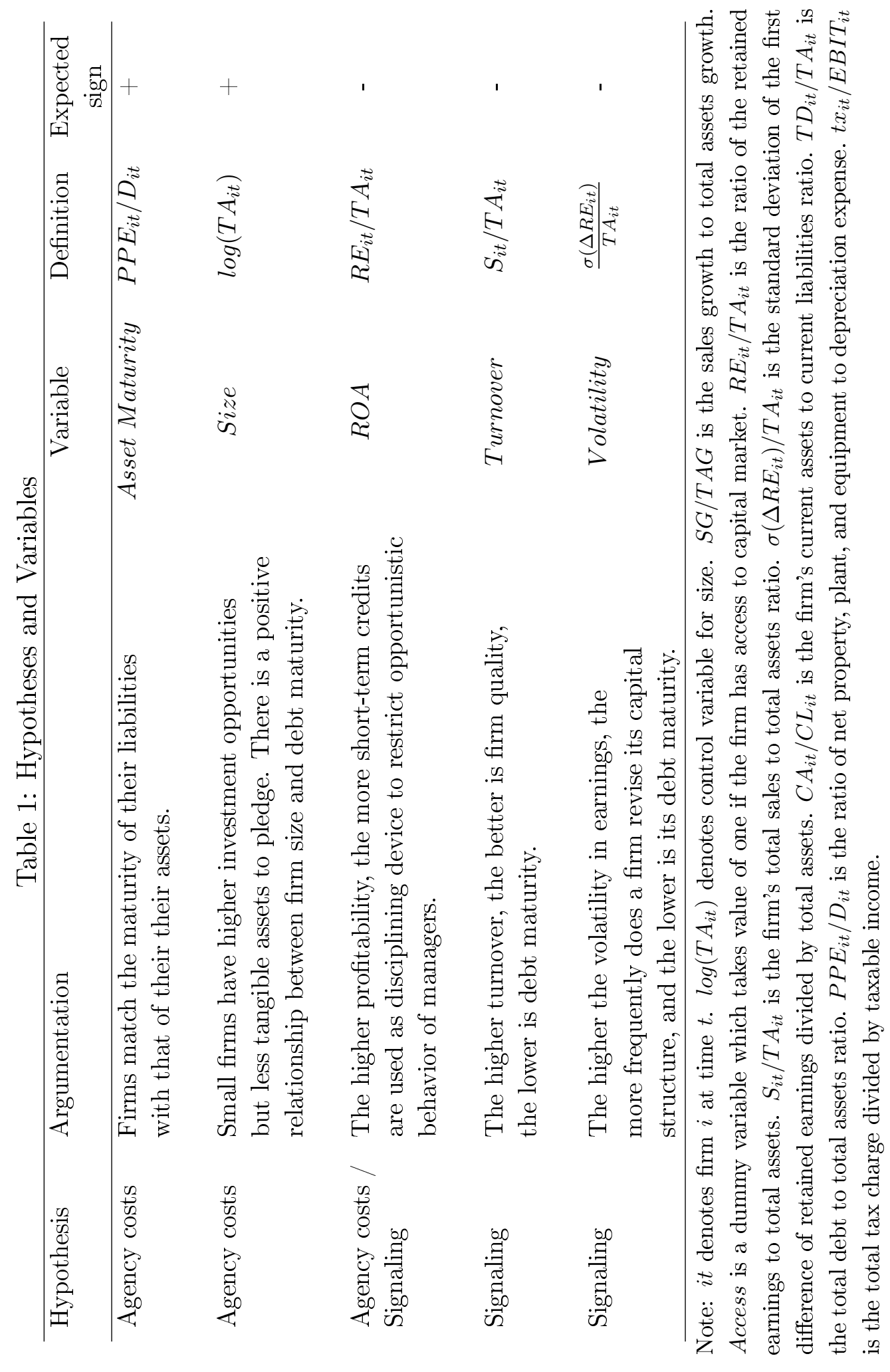




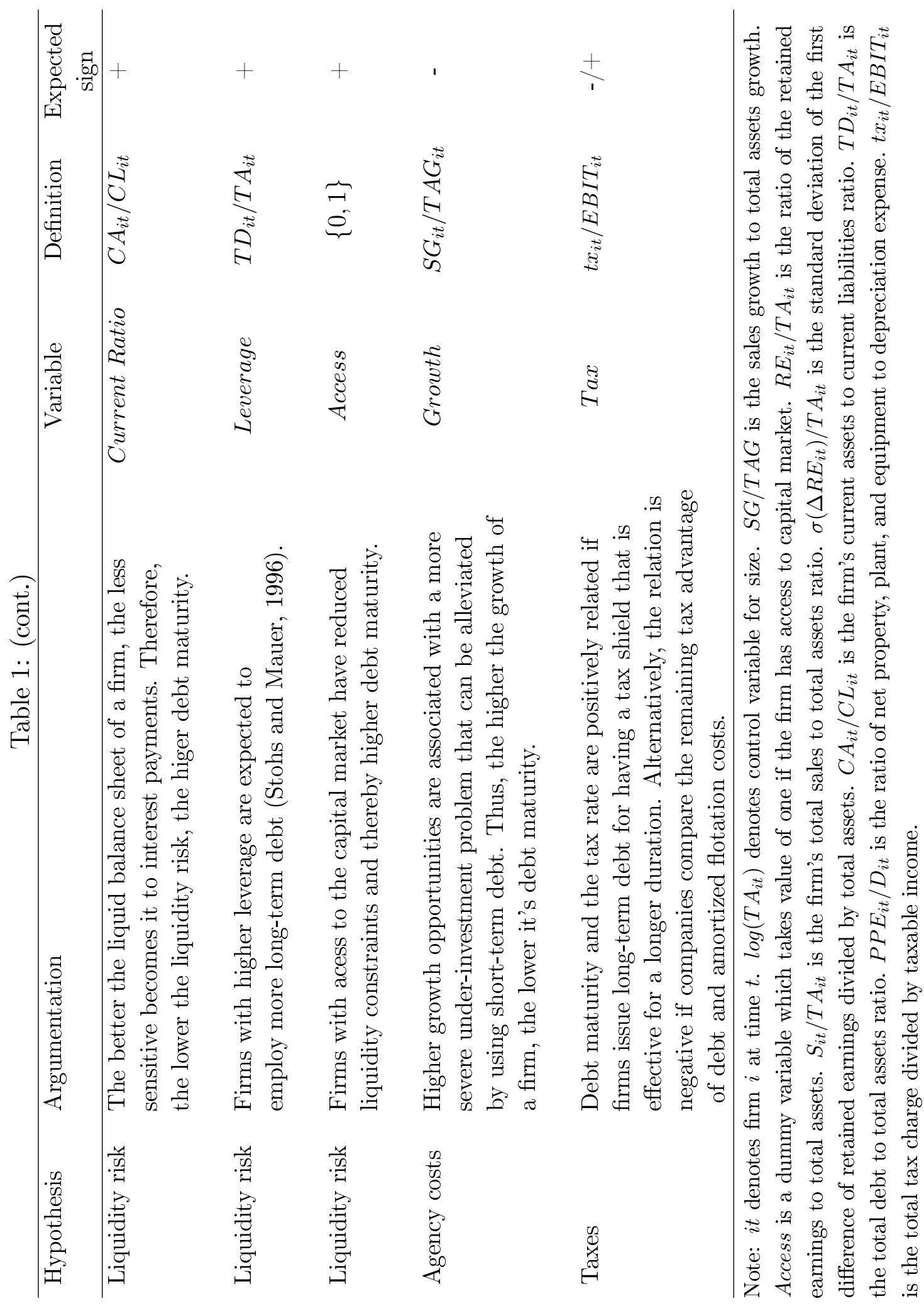


Table 2: Summary statistics for all firms

\begin{tabular}{lcccc}
\hline Variable & $\mu$ & $\sigma$ & Min & Max \\
\hline \hline DebtMaturity & 0.087 & 0.178 & 0.000 & 0.920 \\
Size & 8.387 & 1.503 & 4.758 & 13.467 \\
ROA & -0.014 & 0.096 & -0.624 & 0.400 \\
Volatility & 0.104 & 0.105 & 0.001 & 0.965 \\
Turnover & 0.925 & 1.029 & 0.004 & 8.080 \\
Current Ratio*Leverage & 0.422 & 0.493 & 0.002 & 24.478 \\
Leverage & 0.292 & 0.256 & 0.004 & 1.752 \\
AssetMaturity & 1.113 & 1.013 & 0.108 & 15.000 \\
Tax & 0.134 & 0.213 & 0.000 & 0.953 \\
Growth & 1.301 & 1.006 & 0.071 & 12.744 \\
Access & 0.081 & 0.273 & 0.000 & 1.000 \\
\hline \hline & \multicolumn{5}{c}{$\mathrm{N}=17,462$} \\
\hline
\end{tabular}

Note: DebtMaturity is defined as the ratio of long-term debt to total debt $(L T D / T D)$. Leverage is the firm's debt to total assets ratio. $R O A$ is constructed as retained earnings to total assets ratio. Size is the natural logarithm of total assets, while total assets are measured in thousand Ukrainian Hryvnias (UAH). Turnover is the firm's total sales to total assets ratio. Current Ratio is calculated as the firm's current assets to current liabilities. AssetMaturity is calculated as the ratio of net property, plant, and equipment to depreciation expense. Tax Rate is the total tax charge divided by taxable income. Growth denotes the sales growth to total assets growth ratio. Volatility is the standard deviation of the first difference of retained earnings divided by total assets. Access is a dummy variable which takes value of one if the firm has issued bonds during the observation period. 
Table 3: Summary statistics for small and large firms

\begin{tabular}{lccccc}
\hline & \multicolumn{2}{c}{ Small firms } & \multicolumn{2}{c}{ Large firms } & Wilcoxon \\
Variable & $\mu$ & $\sigma$ & $\mu$ & $\sigma$ & $z$ statistic \\
\hline \hline DebtMaturity & 0.067 & 0.158 & 0.106 & 0.194 & $25.660^{* * *}$ \\
Size & 7.202 & 0.687 & 9.573 & 1.113 & $114.437^{* * *}$ \\
ROA & -0.031 & 0.102 & 0.002 & 0.086 & $25.163^{* * *}$ \\
Volatility & 0.118 & 0.114 & 0.089 & 0.092 & $-20.100^{* * *}$ \\
Turnover & 0.937 & 1.085 & 0.913 & 0.970 & $2.461^{* *}$ \\
Current Ratio* Leverage & 0.378 & 0.407 & 0.467 & 0.564 & $16.620^{* * *}$ \\
Leverage & 0.260 & 0.235 & 0.323 & 0.272 & $14.869^{* * *}$ \\
AssetMaturity & 0.935 & 0.870 & 1.292 & 1.109 & $33.501^{* * *}$ \\
Tax & 0.105 & 0.197 & 0.163 & 0.223 & $23.179^{* * *}$ \\
Growth & 1.305 & 1.022 & 1.298 & 0.990 & 1.318 \\
Access & 0.046 & 0.209 & 0.117 & 0.321 & $17.110^{* * *}$ \\
\hline \hline
\end{tabular}

Note: $*$ significant at $10 \%$; ** significant at $5 \%$; *** significant at $1 \%$. The Wilcoxon $z$-statistic denotes the rank sum test for difference between the respective distributions. DebtMaturity is defined as the ratio of long-term debt to total debt $(L T D / T D)$. Leverage is the firm's debt to total assets ratio. $R O A$ is constructed as retained earnings to total assets ratio. Size is the natural logarithm of total assets. Turnover is the firm's total sales to total assets ratio. Current Ratio is calculated as the firm's current assets to current liabilities. AssetMaturity is calculated as the ratio of net property, plant, and equipment to depreciation expense. Tax Rate is the total tax charge divided by taxable income. Growth denotes the sales growth to total assets growth ratio. Volatility is the standard deviation of the first difference of retained earnings divided by total assets. Access is a dummy variable which takes value of one if the firm has issued bonds during the observation period. 
Table 4: Summary statistics for high- and low-liquidity firms

\begin{tabular}{|c|c|c|c|c|c|}
\hline \multirow[b]{2}{*}{ Variable } & \multicolumn{2}{|c|}{ Low Liquidity } & \multicolumn{2}{|c|}{ High Liquidity } & \multirow{2}{*}{$\begin{array}{l}\text { Wilcoxon } \\
z \text { statistic }\end{array}$} \\
\hline & $\mu$ & $\sigma$ & $\mu$ & $\sigma$ & \\
\hline DebtMaturity & 0.079 & 0.163 & 0.094 & 0.191 & $-4.748^{* * *}$ \\
\hline Size & 8.448 & 1.559 & 8.327 & 1.443 & $-4.218^{* * *}$ \\
\hline$R O A$ & -0.038 & 0.099 & 0.009 & 0.086 & $33.580 * * *$ \\
\hline Volatility & 0.114 & 0.111 & 0.093 & 0.096 & $-14.941^{* * *}$ \\
\hline Turnover & 0.936 & 1.074 & 0.915 & 0.983 & $3.014^{* * *}$ \\
\hline Current Ratio* Leverage & 0.354 & 0.247 & 0.491 & 0.645 & $22.699 * * *$ \\
\hline Leverage & 0.424 & 0.269 & 0.159 & 0.155 & $-75.270 * * *$ \\
\hline AssetMaturity & 1.191 & 1.119 & 1.035 & 0.888 & $-8.898 * * *$ \\
\hline $\operatorname{Tax}$ & 0.107 & 0.199 & 0.160 & 0.222 & $19.742^{* * *}$ \\
\hline Growth & 1.341 & 1.097 & 1.262 & 0.904 & -0.462 \\
\hline Access & 0.091 & 0.288 & 0.072 & 0.258 & $-4.707 * * *$ \\
\hline
\end{tabular}

Note: $*$ significant at $10 \%$; ** significant at $5 \%$; *** significant at $1 \%$. The Wilcoxon $z$-statistic denotes the rank sum test for difference between the respective distributions. DebtMaturity is defined as the ratio of long-term debt to total debt $(L T D / T D)$. Leverage is the firm's debt to total assets ratio. $R O A$ is constructed as retained earnings to total assets ratio. Size is the natural logarithm of total assets. Turnover is the firm's total sales to total assets ratio. Current Ratio is calculated as the firm's current assets to current liabilities. AssetMaturity is calculated as the ratio of net property, plant, and equipment to depreciation expense. Tax Rate is the total tax charge divided by taxable income. Growth denotes the sales growth to total assets growth ratio. Volatility is the standard deviation of the first difference of retained earnings divided by total assets. Access is a dummy variable which takes value of one if the firm has issued bonds during the observation period. 
Table 5: Summary statistics for firms with and without access to capital markets

\begin{tabular}{lccccc}
\hline \multirow{2}{*}{ Variable } & No Access & \multicolumn{2}{c}{ Access } & Wilcoxon \\
& $\mu$ & $\sigma$ & $\mu$ & $\sigma$ & z statistic \\
\hline \hline DebtMaturity & 0.070 & 0.158 & 0.273 & 0.258 & $44.830^{* * *}$ \\
Size & 8.308 & 1.466 & 9.278 & 1.629 & $21.558^{* * *}$ \\
ROA & -0.014 & 0.095 & -0.013 & 0.100 & 1.586 \\
Volatility & 0.103 & 0.104 & 0.108 & 0.115 & -0.202 \\
Turnover & 0.933 & 1.044 & 0.838 & 0.833 & -0.619 \\
Current Ratio* Leverage & 0.400 & 0.409 & 0.673 & 1.016 & $15.640^{* * *}$ \\
Leverage & 0.280 & 0.250 & 0.420 & 0.291 & $19.796^{* * *}$ \\
AssetMaturity & 1.100 & 0.985 & 1.259 & 1.277 & $4.634^{* * *}$ \\
Tax & 0.134 & 0.213 & 0.131 & 0.207 & 0.597 \\
Growth & 1.300 & 1.005 & 1.313 & 1.018 & 1.081 \\
Access & 0 & 0 & 1 & 0 & \\
\hline \hline
\end{tabular}

Note: $*$ significant at $10 \%$; ** significant at $5 \%$; *** significant at $1 \%$. The Wilcoxon $z$-statistic denotes the rank sum test for difference between the respective distributions. DebtMaturity is defined as the ratio of long-term debt to total debt $(L T D / T D)$. Leverage is the firm's debt to total assets ratio. $R O A$ is constructed as retained earnings to total assets ratio. Size is the natural logarithm of total assets. Turnover is the firm's total sales to total assets ratio. Current Ratio is calculated as the firm's current assets to current liabilities. AssetMaturity is calculated as the ratio of net property, plant, and equipment to depreciation expense. Tax Rate is the total tax charge divided by taxable income. Growth denotes the sales growth to total assets growth ratio. Volatility is the standard deviation of the first difference of retained earnings divided by total assets. Access is a dummy variable which takes value of one if the firm has issued bonds during the observation period. 
Table 6: Tobit fixed effects model (panel data)

\begin{tabular}{|c|c|c|c|}
\hline \multicolumn{4}{|c|}{ Dependent variable: DebtMaturity (LTD/TD) } \\
\hline & $\begin{array}{l}\text { All } \\
\text { firms }\end{array}$ & $\begin{array}{l}\text { Small } \\
\text { firms }\end{array}$ & $\begin{array}{l}\text { Large } \\
\text { firms }\end{array}$ \\
\hline$S i z e_{i t-1}$ & $\begin{array}{l}0.0184^{* * *} \\
(5.682)\end{array}$ & $\begin{array}{l}0.0494^{* * *} \\
(2.944)\end{array}$ & $\begin{array}{l}0.0144^{* * *} \\
(2.899)\end{array}$ \\
\hline$R O A_{i t-1}$ & $\begin{array}{c}-0.0242 \\
(1.212)\end{array}$ & $\begin{array}{c}-0.0593^{*} \\
(1.853)\end{array}$ & $\begin{array}{l}0.0145 \\
(0.492)\end{array}$ \\
\hline Turnover $_{i t-1}$ & $\begin{array}{l}-0.0108^{* * *} \\
(4.683)\end{array}$ & $\begin{array}{l}-0.0086^{* *} \\
(2.325)\end{array}$ & $\begin{array}{l}-0.0156^{* * *} \\
(4.301)\end{array}$ \\
\hline Current Ratio $_{i t-1}{ }^{*}$ Leverage $_{i t-1}$ & $\begin{array}{l}0.0625^{* * *} \\
(11.796)\end{array}$ & $\begin{array}{l}0.0667^{* * *} \\
(4.347)\end{array}$ & $\begin{array}{l}0.0621^{* * *} \\
(8.183)\end{array}$ \\
\hline AssetMaturity $_{i t-1}$ & $\begin{array}{l}0.0114^{* * *} \\
(5.726)\end{array}$ & $\begin{array}{l}0.0010 \\
(0.290)\end{array}$ & $\begin{array}{l}0.0179 * * * \\
(5.829)\end{array}$ \\
\hline Growth $_{i t-1}$ & $\begin{array}{c}-0.0027^{*} \\
(1.742)\end{array}$ & $\begin{array}{c}-0.0015 \\
(0.612)\end{array}$ & $\begin{array}{c}-0.0025 \\
(1.172)\end{array}$ \\
\hline $\operatorname{Tax}_{i t-1}$ & $\begin{array}{l}0.0170 * \\
(1.814)\end{array}$ & $\begin{array}{l}0.0427^{* *} \\
(2.327)\end{array}$ & $\begin{array}{c}-0.0027 \\
(0.230)\end{array}$ \\
\hline Volatility ${ }_{i t-1}$ & $\begin{array}{l}0.0021 \\
(0.094)\end{array}$ & $\begin{array}{l}0.0420 \\
(1.137)\end{array}$ & $\begin{array}{l}0.0415 \\
(1.160)\end{array}$ \\
\hline Access $_{t}$ & $\begin{array}{l}0.1465^{* * *} \\
(12.367)\end{array}$ & $\begin{array}{l}0.1899^{* * *} \\
(4.523)\end{array}$ & $\begin{array}{l}0.1370^{* * *} \\
(8.394)\end{array}$ \\
\hline $\begin{array}{l}E(y \mid y>0) \\
\mathrm{N}\end{array}$ & $\begin{array}{l}0.131 \\
17,462\end{array}$ & $\begin{array}{l}0.123 \\
8,731\end{array}$ & $\begin{array}{l}0.146 \\
8,731\end{array}$ \\
\hline
\end{tabular}

Note: Each equation includes year dummies which are not reported. t-values are reported in parentheses. * significant at 10\%; ** significant at 5\%; *** significant at $1 \%$. DebtMaturity is defined as the ratio of long-term debt to total debt $(L T D / T D)$. Leverage is the firm's debt to total assets ratio. $R O A$ is constructed as retained earnings to total assets ratio. Size is the natural logarithm of total assets. Turnover is the firm's total sales to total assets ratio. Current Ratio is calculated as the firm's current assets to current liabilities multiplied with Leverage. AssetMaturity is calculated as the ratio of net property, plant, and equipment to depreciation expense. Tax Rate is the total tax charge divided by taxable income. Growth denotes the sales growth to total assets growth ratio. Volatility is the standard deviation of the first difference of retained earnings divided by total assets. Access is a dummy variable which takes value of one if the firm has issued bonds during the observation period. 
Table 7: Tobit fixed effects model (panel data) - Role of financial constraints

\begin{tabular}{|c|c|c|c|c|}
\hline \multicolumn{5}{|c|}{ Dependent variable : DebtMaturity (LTD/TD) } \\
\hline & Low & High & No & \\
\hline & Liquidity & Liquidity & Access & Access \\
\hline$S i z e_{i t-1}$ & $\begin{array}{l}0.0094^{* * *} \\
(2.755)\end{array}$ & $\begin{array}{l}0.0310^{* * *} \\
(5.024)\end{array}$ & $\begin{array}{l}0.0223^{* * *} \\
(5.678)\end{array}$ & $\begin{array}{l}-0.0127^{* *} \\
(2.077)\end{array}$ \\
\hline$R O A_{i t-1}$ & $\begin{array}{c}-0.0307 \\
(1.184)\end{array}$ & $\begin{array}{c}-0.0114 \\
(0.281)\end{array}$ & $\begin{array}{l}-0.0433^{* *} \\
(2.035)\end{array}$ & $\begin{array}{l}0.0856 \\
(1.193)\end{array}$ \\
\hline Turnover $_{i t-1}$ & $\begin{array}{l}-0.0163^{* * *} \\
(5.278)\end{array}$ & $\begin{array}{l}-0.0122^{* * *} \\
(2.672)\end{array}$ & $\begin{array}{l}-0.0075^{* * *} \\
(3.218)\end{array}$ & $\begin{array}{l}-0.0379 * * * \\
(3.597)\end{array}$ \\
\hline Current Ratio $_{i t-1}{ }^{*}$ Leverage $_{i t-1}$ & $\begin{array}{l}0.1048^{* * *} \\
(7.074)\end{array}$ & $\begin{array}{l}0.0588^{* * *} \\
(9.408)\end{array}$ & $\begin{array}{l}0.0715^{* * *} \\
(10.024)\end{array}$ & $\begin{array}{l}0.0419^{* * *} \\
(6.801)\end{array}$ \\
\hline AssetMaturityit-1 & $\begin{array}{l}0.0126^{* * *} \\
(5.148)\end{array}$ & $\begin{array}{l}0.0194^{* * *} \\
(4.629)\end{array}$ & $\begin{array}{l}0.0074^{* * *} \\
(3.571)\end{array}$ & $\begin{array}{l}0.0364^{* * *} \\
(6.939)\end{array}$ \\
\hline Growth $_{i t-1}$ & $\begin{array}{l}-0.0040 * * \\
(2.048)\end{array}$ & $\begin{array}{c}-0.0022 \\
(0.691)\end{array}$ & $\begin{array}{c}-0.0010 \\
(0.629)\end{array}$ & $\begin{array}{l}-0.0147^{* * *} \\
(2.901)\end{array}$ \\
\hline $\operatorname{Tax}_{i t-1}$ & $\begin{array}{l}0.0086 \\
(0.655)\end{array}$ & $\begin{array}{l}0.0268^{*} \\
(1.704)\end{array}$ & $\begin{array}{l}0.0212^{* *} \\
(2.208)\end{array}$ & $\begin{array}{l}0.0094 \\
(0.269)\end{array}$ \\
\hline Volatility $_{i t-1}$ & $\begin{array}{l}0.0422 \\
(1.519)\end{array}$ & $\begin{array}{c}-0.0549 \\
(1.211)\end{array}$ & $\begin{array}{c}-0.0223 \\
(0.955)\end{array}$ & $\begin{array}{l}0.1082 \\
(1.572)\end{array}$ \\
\hline Access $_{t}$ & $\begin{array}{l}0.1403^{* * *} \\
(9.874) \\
\end{array}$ & $\begin{array}{l}0.1683^{* * *} \\
(9.322) \\
\end{array}$ & & \\
\hline $\begin{array}{l}E(y \mid y>0) \\
\mathrm{N}\end{array}$ & $\begin{array}{l}0.130 \\
8,731\end{array}$ & $\begin{array}{l}0.167 \\
8,731\end{array}$ & $\begin{array}{l}0.119 \\
16,042\end{array}$ & $\begin{array}{l}0.294 \\
1,420\end{array}$ \\
\hline
\end{tabular}

Note: Each equation includes year dummies which are not reported. t-values are reported in parentheses. * significant at $10 \%$; ** significant at 5\%; *** significant at $1 \%$. DebtMaturity is defined as the ratio of long-term debt to total debt $(L T D / T D)$. Leverage is the firm's debt to total assets ratio. $R O A$ is constructed as retained earnings to total assets ratio. Size is the natural logarithm of total assets. Turnover is the firm's total sales to total assets ratio. Current Ratio is calculated as the firm's current assets to current liabilities which is multiplied with Leverage. AssetMaturity is calculated as the ratio of net property, plant, and equipment to depreciation expense. Tax Rate is the total tax charge divided by taxable income. Growth denotes the sales growth to total assets growth ratio. Volatility is the standard deviation of the first difference of retained earnings divided by total assets. Access is a dummy variable which takes value of one if the firm has issued bonds during the observation period. 